\title{
Surface Water Quality Response to Land Use Land Cover Change in an Urbanizing Catchment: A Case of Upper Chongwe River Catchment, Zambia
}

\author{
Alick Nguvulu1 ${ }^{*}$, Agabu Shane², Claude S. Mwale ${ }^{3}$, Tewodros M. Tena ${ }^{3}$, Phenny Mwaanga ${ }^{3}$, \\ John Siame ${ }^{4}$, Brian Chirambo ${ }^{3}$, Musango Lungu ${ }^{4}$, Frank Mudenda ${ }^{5,6}$, Dickson Mwelwa ${ }^{7}$, \\ Sydney Chinyanta ${ }^{2}$, Jackson Kawala², Victor Mwango Bowa'2 Levi S. Mutambo', \\ Nicholas Okello' ${ }^{1}$, Charles Musonda ${ }^{1}$
}

\footnotetext{
${ }^{1}$ Department of Geomatics Engineering, Copperbelt University, Kitwe, Zambia

${ }^{2}$ Department of Mining Engineering, Copperbelt University, Kitwe, Zambia

${ }^{3}$ Department of Environmental Engineering, Copperbelt University, Kitwe, Zambia

${ }^{4}$ Department of Chemical Engineering, Copperbelt University, Kitwe, Zambia

${ }^{5}$ Department of Civil Engineering, University of Pretoria, Pretoria, South Africa

${ }^{6}$ Department of Civil and Environmental Engineering, University of Zambia, Lusaka, Zambia

${ }^{7}$ Business and Information Technology Department, Cavendish University, Lusaka, Zambia

Email: *anguvulu2000@yahoo.co.uk
}

How to cite this paper: Nguvulu, A., Shane, A., Mwale, C.S., Tena, T.M., Mwaanga, P., Siame, J., Chirambo, B., Lungu, M., Mudenda, F., Mwelwa, D., Chinyanta, S., Kawala, J., Bowa, V.M., Mutambo, L.S., Okello, N. and Musonda, C. (2021) Surface Water Quality Response to Land Use Land Cover Change in an Urbanizing Catchment: A Case of Upper Chongwe River Catchment, Zambia. Journal of Geographic Information System, 13, 578-602.

https://doi.org/10.4236/jgis.2021.135032

Received: July 9, 2021

Accepted: October 24, 2021

Published: October 27, 2021

\begin{abstract}
The Upper Chongwe River Catchment has recently been overexploited for water resources with increased complaints by various water users about the deteriorating quality of surface water within the sub-catchment. This study was motivated by the need to investigate and understand the response of surface water quality to land use land cover (LULC) change due to urbanization. Water samples, collected at 9 sampling sites from 2006 to 2017, were analyzed for water quality using the weighted arithmetic water quality index and trend using the Mann-Kendall statistics. LULC change is detected and analyzed in ERDAS Imagine 2014 and ArcGIS 10.4 using 2006 Landsat 5 TM and 2017 Landsat 8 OLI imageries. The relationship between LULC change and water quality was performed with multiple regression analysis and Pearson correlation. The results reveal that Built-up area, Grassland and surface water increased by $5.48 \%, 13.34 \%$ and $0.03 \%$ respectively while Agricultural land and Forest Land decreased by $-13.41 \%$ and $-5.42 \%$ respectively. The water quality index ranged from 43.04 to 110.40 in 2006 and from 170 to 430 in 2017 indicating a deterioration in the quality of surface water from good to unsuitable for drinking at all the sampled sites. Built-up/bare lands exhibited a sig-
\end{abstract}


Copyright $\odot 2021$ by author(s) and Scientific Research Publishing Inc. This work is licensed under the Creative Commons Attribution International License (CC BY 4.0).

http://creativecommons.org/licenses/by/4.0/

Open Access nificant positive correlation with EC $\left(R^{2}=0.61, \mathrm{p} \leq 0.05\right)$, turbidity $\left(R^{2}=\right.$ $0.69, \mathrm{p} \leq 0.05)$, TDS $\left(R^{2}=0.61, \mathrm{p} \leq 0.05\right), \mathrm{Cl}\left(R^{2}=0.62, \mathrm{p} \leq 0.05\right)$ and a significant negative correlation with $\mathrm{NH}_{4}\left(R^{2}=-0.729, \mathrm{p} \leq 0.05\right)$. Agriculture exhibited a significant positive correlation with turbidity $\left(R^{2}=0.71, \mathrm{p} \leq 0.01\right)$ and $\mathrm{Fe}\left(R^{2}=0.75, \mathrm{p} \leq 0.01\right.$. Forest cover correlated negatively with most of the water quality parameters apart from $\mathrm{Fe}, \mathrm{DO}, \mathrm{NO}_{3}$ but was not statistically significant. Grassland had a significant negative correlation with temperature $\left(R^{2}\right.$ $=-0.68, \mathrm{p} \leq 0.05)$. Clearly, urbanization has made a disproportionately strong contribution to the deterioration of surface water quality indicating that intensive anthropogenic activities exacerbate water quality degradation. These results provide essential information for land use planners and water managers towards sustainable and equitable management of limited water resources.

\section{Keywords}

Water Quality, LULC Change, Water Quality Index, River Catchment, Watershed

\section{Introduction}

River catchments play a significant role in the provision of water for domestic, agricultural and industrial purposes. Nevertheless, as observed by Reed et al. [1] and Avivor \& Gordon [2], land use dynamics within river catchments have negative repercussions on river health. Usually triggered by population growth within a catchment area, urban land use dynamics often present themselves in form of large swaths of land being cleared to meet the increasing need for built-up area and agricultural use on one hand and high demand for water on the other. Such landscape dynamics tend to alter the natural ecosystem leading to loss of biodiversity, cause water fluxes and compromise water quality in lakes, rivers and streams within a catchment [3] [4] [5]. Therefore, revealing the relationship between land use change and water quality is of great significance to watershed protection.

Several studies have revealed that there is a significant correlation between land use land cover change and water quality. Hua [6] observed that land use dynamics in a watershed negatively impacts on water quality and indirectly affect the nature of a watershed ecosystem. This could arise from such factors as loss of wetlands, discharge from septic and sewer systems, airborne discharge from vehicles and wood-burning stoves, increased sediment and nutrient loading. Study by Huang et al. [7] has shown that the relationship between land use land cover (LULC) change and surface water quality parameters is generally positive in the case of cropland and built-up areas, (when planned and managed well), negative with forest, grassland and sandy areas, and varies in the case of cultivated land.

Located in the rapidly urbanizing region of Zambia, the Chongwe River Cat- 
chment has been experiencing increased development activities that have triggered extensive LULC change in the recent past [8]. Extensive irrigation zones have mushroomed in the north, northeast, east, south and northwestern parts of the catchment while the central and western parts have seen increased urbanization [9]. Irrigated agriculture in the catchment depends largely on dammed water along the Chongwe River and its main tributaries. The catchment is under water stress and consequently, a great majority of the population lack access to good drinking water and good sanitation [10] [11] [12]. The challenges of water scarcity in the catchment seem to be compounded by severe biochemical and sewage pollution in the Chongwe River and its tributaries upstream.

In studying the relationship between LULC and water quality, several researchers have applied various statistical techniques including multivariate methods, linear models and redundancy approaches. For example, Li et al. [13] (2008) studied water quality in relation to land use and land cover in the Upper Han River Basin in China using multivariate analysis. From their work, it was concluded that agricultural and urban areas contribute to water quality degradation while forest cover plays an important role in keeping the water clean. Chen et al. [14] (2020) used Pearson correlation to determine the relationship between Land Use Change and Water Quality of the Mitidja Watershed in Algeria. From the results, urban settlement area was found to be a predictor for $\mathrm{NH}_{4}-\mathrm{N}, \mathrm{BOD}_{5}$, $\mathrm{COD}, \mathrm{SS}, \mathrm{PO}_{4}-\mathrm{P}, \mathrm{DO}$ and $\mathrm{pH}$, while vegetation was a predictor for $\mathrm{NO}_{3}-\mathrm{N}$. As observed by $\mathrm{Tu}$ [15], the relationship between land use and water quality varies significantly over space and geographic locations mainly due to the different catchment physiognomies and pollution sources. Other studies have, in fact, observed that land use on riparian-buffer scale influences water quality better than on a catchment scale [16] [17], while others hold that catchment scale better influences the water quality [18] [19].

Several water studies in the Chongwe River Catchment have been undertaken. However, these studies have focused mainly on groundwater quality [20] and development of a groundwater information and management program for the Lusaka groundwater systems [21]. The outputs of these studies include 1) a land use map of Lusaka and surroundings [22],2) discharge measurements and rating curves [23], 3) description of physiography, geology, climate, hydrology and the groundwater systems of the area [9], and 4) hydrological, hydrogeological and hydrochemical characterization of groundwater resources [24]. There has been no specific study done to establish the relationship between LULC change, and surface water quality in the sub-catchment.

This study is motivated by the need to analyse and understand the response of surface water quality to LULC change in the rapidly urbanizing Chongwe River Catchment. This sub-catchment is of strategic importance to the socio-economic wellbeing of Zambia as it covers the most rapidly urbanizing City of Lusaka, the Capital of Zambia. The rapid population growth in Lusaka City has placed the Chongwe River Catchment under great water and land-use pressure, as the de- 
mand for these resources has clearly increased. The study adopts the PCA, Kendal trend analysis, Pearson correlation and multiple regression approaches. The output of the study will contribute to the water resources management knowledge base and inform policy framework on sustainable water resources management in a rapidly urbanizing sub-catchment of a low-income country.

\section{Study Area and Data}

\subsection{Study Area}

The Chongwe River Catchment is located between $14^{\circ} 55^{\prime} 40^{\prime \prime} \mathrm{S}-15^{\circ} 43^{\prime} 19^{\prime \prime} \mathrm{S}$ and $28^{\circ} 13^{\prime} 53^{\prime \prime E}-29^{\circ} 21^{\prime} 24^{\prime \prime E}$ (Figure 1). Spanning a total area of $5168.68 \mathrm{Km}^{2}$ [25], the catchment covers parts of the Districts of Lusaka, Chongwe, Chibombo, Chisamba and Kafue. Further, a very small fraction of the Luangwa District is inside the Lower Chongwe Sub-catchment [9]. The estimated population for the Chongwe River Catchment is over 834,359 with a growth rate of 4.9\% per annum.

The Chongwe River catchment can be divided into upper, middle and lower parts. The predominant land use in the upper and middle half is agriculture and livestock production. About 6500 ha of land is now cultivated under a variety of irrigation schemes and methods in both large- and small-scale farming. The main crops grown are wheat, maize, beans, groundnut, cotton, vegetables, flowers, and horticultural crops. The other middle half is predominantly a built-up area. The lower part is mainly forest and bushland providing valuable habitat for wild animals and birds. It is also one of the ecotourism sites in Zambia. Small scale river bank cultivation and fishing are common practices by the local community in the lower part providing a means of income and household food security.

The climate of Chongwe River catchment is described as humid subtropical, Location of Chongwe River Catchment in Zambia

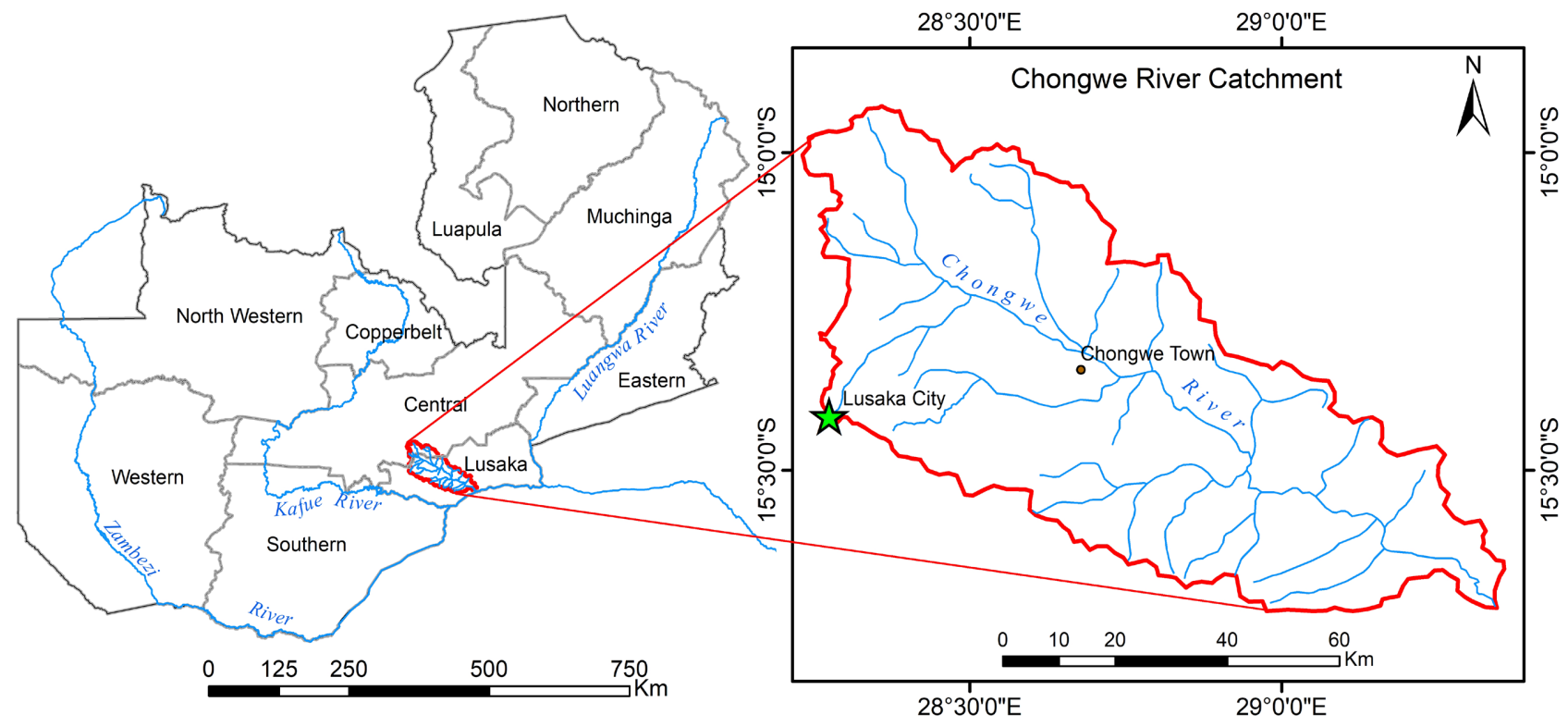

Figure 1. Location of the Chongwe River Sub-catchment in Zambia. 
with dry winters and hot summers. The warmer wet season starts in mid-September and extends through May. Precipitation peaks high in December and January at around $232 \mathrm{~mm} /$ month. The colder dry season is from June through August with little or no precipitation and long dry spells. Average maximum air temperatures peak in October around $32^{\circ} \mathrm{C}$, while average minimum air temperature is $8.2^{\circ} \mathrm{C}$ occurring in July. The vegetation of Chongwe River catchment is classified as Miombo woodland, dominated by semi-evergreen trees with a well-developed grass layer.

The prevailing lithologies of the catchment are Schists, Quartzites and Basement Complex Rocks (Gneiss and Granite mainly). The upper part of the catchment contains Metasedimentary Rocks of Katanga age intruded by granitic and basic bodies while the south-western half (Middle Chongwe) part has Schists and Carbonate Rocks (mainly, Dolomitics Limestone and Dolomites). The lower part making up the north-western half of the catchment (mainly the Zambezi escarpment) is dominated by basement complex with Quartzites and Schists [17] [26].

\subsection{Data}

Two dataset types, i.e. spatial and nonspatial datasets, were used in this study. The spatial dataset comprised of 1) a Shuttle Radar Topography Mission (SRTM) 1 Arcsec Global Digital Elevation Model (DEM); 2) 3 Landsat 5 Thematic Mapper (TM) images for the month of July 2006 and 3 Landsat 8 Operational Land Imager (OLI) images for the month of July 2017, (both the SRTM DEM and Landsat images were obtained from the United States Geological Survey (USGS); 3) 1:50,000 topographical maps from the Zambia Survey Department (ZSD); and 4) ground control points (GCPs) collected using Global Positioning System (GPS) during field visits and Google Earth. The nonspatial dataset comprised of monthly water quality data for the period 2006-2016. These were obtained from the Zambia Water Resources Management Authority (WARMA) database, water quality reports from the Zambia Environmental Management Agency (ZEMA) and authors' own water quality field and lab measurements for 2017.

\section{Methods}

\subsection{Chongwe River Catchment Delineation}

First, a field reconnaissance survey was conducted to have a visual understanding of the study area. Then the $30 \mathrm{~m}$ spatial resolution SRTM DEM was preprocessed by filling sinks in the DEM and the catchment boundary delineated following a series of steps using ArcHydro tools in ArcGIS 10.4. The stream network was onscreen digitized from the ZSD topographic maps and updated further with Google Earth Images. Landsat image pre-processing involved geometrically rectifying and reprojecting the visible and near infrared bands to UTM Zone 35 South, WGS 1984. The rectified and reprojected bands were then 
clipped using the Chongwe River Catchment boundary delineated earlier and later combined to generate two multispectral images for 2006 (Landsat 5 TM) and 2017 (Landsat 8 OLI) to be used in the LULC classification and change detection. These later steps were achieved in ERDAS Imagine 2014.

\subsection{LULC Classification and Change Detection}

Supervised image classification was performed on the Landsat 5 TM and 8 OLI multispectral images for the reference years 2006 and 2017 using the Maximum Likelihood Classifier (MLC) parametric decision rule. The MLC calculates a Bayesian probability function for each pixel from the inputs for classes established from training sites and then assigns the pixel to a class to which it most probably belongs [27] [28]. The classification was based on a predefined LULC classification scheme developed from the authors' field knowledge of the catchment. The scheme consisted of five classes namely built-up area, agriculture land, forest land, ranch/grassland and water bodies. After the class signatures were generated for each class, the images were then classified with appropriate colors and names for easy interpretation of classes. This process was repeated several times while comparing with a Google Earth images before settling for a suitable classified image on which to generate statistics for each class. The change detection analysis was done by comparing the 2006 and 2017 thematic images using confusion matrix operation. All the above operations were done in ERDAS Imagine 2014 and ArcGIS 10.4. The changes in LULC were expressed both in absolute and percentage proportions [29].

\subsection{LULC Classification Accuracy Assessment}

The image classification accuracy was assessed using the overall accuracy, producer's accuracy, and user's accuracy were determined in addition to the Kappa Coefficient $(K)$ [30]. The Kappa coefficient is widely used because all elements in the classification error matrix, and not just the main diagonal, contribute to its calculation and because it compensates for change agreement. The Kappa coefficient lies typically on a scale between 0 (no reduction in error) and 1 (complete reduction of error). The latter indicates complete agreement, and is often multiplied by 100 to give a percentage measure of classification accuracy. In practice, the agreement is taken to be strong when $K$ is greater than $0.80(80 \%)$, moderate when $K$ values fall between $0.40(40 \%)$ and $0.80(80 \%)$ and poor when $K$ values are less than $0.40(40 \%)$ [31].

\subsection{Selection of Water Quality Parameters, Sampling Sites and Frequency of Sampling}

The parameters selected for water quality analysis were $\mathrm{pH}$, temperature, turbidity, electrical conductivity (EC), total dissolved solids (TDS), biological oxygen demand (BOD5), total phosphates $\left(\mathrm{PO}_{5}\right)$, nitrate $\left(\mathrm{NO}_{3}\right)$, ammonia $\left(\mathrm{NH}_{3}\right)$, sulphate $\left(\mathrm{SO}_{4}\right)$ and heavy metals (chromium, cadmium, iron and lead). Water samples were collected from 9 sampling sites shown in Figure 2. The sampling sites 


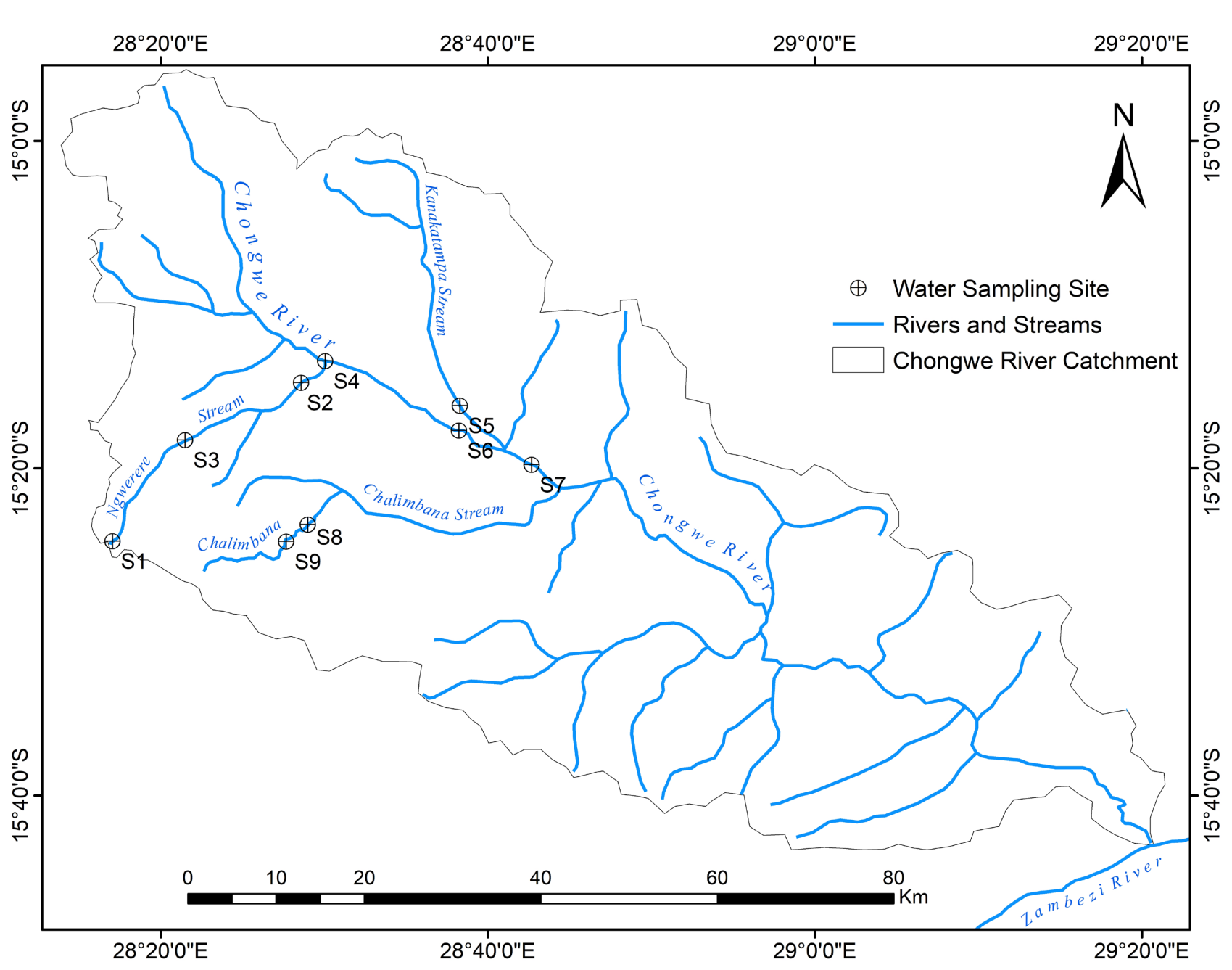

Figure 2. Water sampling sites in the study area.

were grouped into three zones namely 1) Upstream (Sites S1 - S4) 2) Midreach (Sites S5 - S7), and 3) Downstream (Sites 8 - 9) Zones. The frequency of sampling was determined based on the reference data comprising of the WARMA quality monitoring data for 2006.

\subsection{Water Sampling and Analysis of Physical, Chemical and Biological Quality Parameters}

Sampling and analyses, under Good Laboratory Practice conditions [32] [33] [34] [35], were conducted three times each month in February and July of 2017 and 2018 at the same sampling sites shown in Figure 2. The two months of sampling were considered because results of analysis were comparable with the WARMA water quality dataset from 2006 to 2016. All sampling equipment were sterilized and rinsed with distilled water before sampling. On the sampling site, the first step was in-situ analysis of physical parameters which included Temperature, TDS, EC, $\mathrm{pH}$, and DO. The process was then followed by collection and preservation of water samples for chemical analysis. Sample bottles for heavy metals were preserved with $2 \mathrm{ml}$ of Nitric Acid while those used for BOD5 
were filled to the bream to avoid air contamination [35]. The samples were taken to the laboratory for analysis within $8 \mathrm{~h}$.

On-site analysis equipment for $\mathrm{pH}$, TDS, Temperature, and Turbidity were calibrated before analysis while their probes were rinsed with distilled water before taking the readings. Sampling time was conducted in the morning to avoid extreme temperature variations. After sampling, each of the triplet $500 \mathrm{ml}$ were clearly labeled and stored in cooler boxes filled with ice cubes as a measure of maintaining a refrigerant temperature before laboratory analysis. Additionally, the analyses of physicochemical and biological parameters were carried out with the aid of local and international water quality compliance limits and guidelines [32] [36] [37]. Table 1 summarizes the methods, equipment and protocols used in both the in-situ and laboratory analyses.

\subsection{Trend Analysis of Water Quality}

The trend of the measured values of water quality variables is analyzed using the Mann-Kendall's t test. The Mann-Kendall's $t$ statistic is one of the non-parametric test commonly employed to detect monotonic trends in series of environmental, climate or hydrological data [38] [39] [40]. Kendall's t test first ranks all observations by date order, then the difference between each consecutive value is

Table 1. Characterization parameters and analytical methods used in the study.

\begin{tabular}{|c|c|c|c|c|}
\hline Parameter & Unit & Equipment/Analysis Method & ${ }^{\mathrm{a}} \mathrm{APHA}$ Protocol & $\begin{array}{c}\text { Equipment } \\
\text { Used }\end{array}$ \\
\hline $\mathrm{pH}$ & & $\mathrm{pH}$ meter & $4500-\mathrm{H}+$ & EUTECH \\
\hline Temperature & ${ }^{\circ} \mathrm{C}$ & Conductivity meter & 2550 & WAGTECH \\
\hline Dissolved Oxygen (DO) & $\mathrm{mg} / \mathrm{L}$ & Dissolved Oxygen Meter & $4500-\mathrm{H}+$ & EUTECH \\
\hline Total Dissolved Solids (TDS) & $\mathrm{mg} / \mathrm{L}$ & Conductivity meter & 2550 & WAGTECH \\
\hline Turbidity & NTU & Turbidity meter & $2130 \mathrm{~B}$ & $\mathrm{HACH}$ \\
\hline Electrical Conductivity (EC) & $\mathrm{ms} / \mathrm{cm}$ & Conductivity meter & 2550 & WAGTECH \\
\hline Biological Oxygen Demand (BOD) & $\mathrm{mg} / \mathrm{L}$ & Wrinkle Method & & \\
\hline Chemical Oxygen Demand (COD) & $\mathrm{mg} / \mathrm{L}$ & Titration (Open reflux Method) & $5220 \mathrm{C}$ & \\
\hline Nitrate $\left(\mathrm{NO}_{3}\right)$ & $\mathrm{mg} / \mathrm{L}$ & Spectrometer & $4500-\mathrm{NO}_{3}-\mathrm{B}$ & \\
\hline Phosphate $\left(\mathrm{PO}_{4}\right)$ & $\mathrm{mg} / \mathrm{L}$ & Spectrometer & $4500-\mathrm{PE}$ & \\
\hline Sulphate $\left(\mathrm{SO}_{4}^{2-}\right)$ & $\mathrm{mg} / \mathrm{L}$ & Atomic Absorption Spectrometer & $4500-\mathrm{SO}_{4} \mathrm{E}$ & \\
\hline Iron $(\mathrm{Fe})$ & $\mathrm{mg} / \mathrm{L}$ & Atomic Absorption Spectrometer & $3111 \mathrm{~B}$ & AA240 \\
\hline Lead $(\mathrm{Pb})$ & $\mathrm{mg} / \mathrm{L}$ & Atomic Absorption Spectrometer & $3111 \mathrm{~B}$ & AA240 \\
\hline Chromium (Cr) & $\mathrm{mg} / \mathrm{L}$ & Atomic Absorption Spectrometer & $3111 \mathrm{~B}$ & AA240 \\
\hline Cadmium (Cd) & $\mathrm{mg} / \mathrm{L}$ & Atomic Absorption Spectrometer & $3111 \mathrm{~B}$ & AA240 \\
\hline Potassium $\left(\mathrm{K}^{+}\right)$ & $\mathrm{mg} / \mathrm{L}$ & Atomic Absorption Spectrometer & $3111 \mathrm{~B}$ & AA240 \\
\hline Sodium $\left(\mathrm{Na}^{+}\right)$ & $\mathrm{mg} / \mathrm{L}$ & Atomic Absorption Spectrometer & $3111 \mathrm{~B}$ & AA240 \\
\hline
\end{tabular}

a. APHA: American Public Health Association. 
calculated and the sum of the signs of these differences is calculated as the Kendall sum, $S$, statistic as in

$$
s=\sum_{j=k}^{n-1} \sum_{j=k+1}^{n} \operatorname{sgn}\left(x_{j}-x_{k}\right)
$$

where $\operatorname{sgn}\left(x_{j}-x_{k}\right)$ is as in

$$
\operatorname{sgn}\left(x_{j}-x_{k}\right)= \begin{cases}1 & \text { if }\left(x_{j}-x_{k}\right)>0 \\ 0 & \text { if }\left(x_{j}-x_{k}\right)=0 \\ -1 & \text { if }\left(x_{j}-x_{k}\right)<0\end{cases}
$$

The expected value $E($.) of $S$ is and its variance, $\operatorname{Var}($.$) is as in$

$$
\operatorname{Var}(s)=\left[n(n-1)(2 n+5)-\sum_{t} t(t-1)(2 t+5)\right] / 18
$$

where $t$ indicates the extent of any given time and $\sum_{t}$ denotes the sum across all the ties in the water quality data. For $n>0$, the standard normal variant is calculated as in

$$
z= \begin{cases}(s-1) / \sqrt{\operatorname{Var}(s)} & \text { if } s>0 \\ 0 & \text { if } s=0 \\ (s+1) / \sqrt{\operatorname{Var}(s)} & \text { if } s<0\end{cases}
$$

Under the Kendall's $t$ test, a positive value of $S$ in Equation 4 indicates an increasing trend whereas a negative value indicates a decreasing trend. Under this ( $t)$ test, the following were the hypotheses: Null hypothesis, H0: There is no trend in the water quality. Alternative hypothesis, Ha: There is a trend in the water quality. The decision to reject the null hypothesis proceeds in the same fashion as standard tests of hypotheses of significance. That is, if the p-value of the test is less than the level of significance, the null hypothesis is rejected, but if the reverse is the case, then the null hypothesis is not rejected. Kendall's $t$ test of significance was carried out in XL Stat 2014. All tests of significance were two-sided and considered significant at the 0.05 level.

\subsection{Multivariate Analysis}

In this study, the multivariate statistical techniques of Factor analysis (FA) and Hierarchical Cluster analysis (HCA) are used. First the raw data is standardized by subtracting the mean of the data set from each variable and dividing by the standard deviation to produce a normal distribution. The HCA approach using Ward Method is then applied to group sampling sites into clusters and homogeneous groups of variables are represented through a dendogram based on selected sample locations. The HCA is expressed mathematically as in

$$
d_{i j}^{2}=\sum_{j=k}^{m}\left(z_{i k}-z_{j k}\right)^{2}
$$

where $d_{i j}^{2}$ is the Euclidean distance, $z_{i k}$ is the values of variable $k$ for object $i$; $z_{j k}$ is the values of variable $k$ for object $j$, and $m=$ the number of variables. 
The Principal Component Analysis (PCA) is then used to evaluate selected parameters through a correlation matrix. The PCA is specifically used to extract the factors with correlated values while at the same time giving spatial and temporal changes in the water quality [41] [42]. The PCA is expressed mathematically as in

$$
z_{i j}=a_{i 1} x_{1 j}+a_{i 2} x_{2 j}+a_{i 3} x_{3 j}+\cdots+a_{i m} x_{m j}
$$

where, $z=$ component score, $a=$ component loading, $x=$ measured value of variable, $i=$ component number, $j=$ sample number, and $m=$ the total number of variables. Factor analyses were used to determine the pollution factors affecting the water quality among the sampling sites where factor loading value $>0.75$ is described as "strong" loading, $0.75-0.50$ is "moderate" and $0.50-030$ is described as "weak".

\subsection{Weighted Arithmetic Water Quality Index}

The weighted arithmetic water quality index $\left(W Q I_{A}\right)$ [43] [44] [45] is used to rate the water quality of our study area. The application of $W Q I_{A}$ is done to determine the suitability of surface water for human consumption [46]. The $W Q I_{A}$ can be expressed mathematically as in

$$
W Q I_{A}=\frac{\sum_{i=1}^{n} w_{i} q_{i}}{\sum_{i=1}^{n} w_{i}}
$$

where $n$ is the number of parameters, $w_{i}$ is the relative weight of the $i$ th parameter and $q_{i}$ is the water quality rating of the $i$ th parameter. The unit weights $\left(w_{i}\right)$ of the various water quality parameters are inversely proportional to the recommended standards for the corresponding parameters [47]. The value of $q_{i}$ is calculated as in

$$
q_{i}=100 \times\left(\frac{V_{i}-V_{i d}}{S_{i}-V_{i d}}\right)
$$

where $V_{i}$ is the observed value of the $i$ th parameter, $S_{i}$ is the standard permissible value of the $i$ th parameter and $V_{i d}$ is the ideal value of the $i$ th parameter in pure water.

\subsection{Determining the Relationship between LULC Change and Water Quality}

The relationship between land use and water quality was performed with multiple regression analysis and Pearson correlation. The correlation analysis developed a correlation matrix between the land use types and water quality in order to determine the type of interaction between them. Moreover, the multiple regression analysis explained the magnitude and influence of the land use (predictor variables) on water quality parameters (response variables). Stronger positive correlation showed values closer to 1 and those closer to 1 showed a stronger negative correlation between variables. 


\section{Results and Discussion}

\subsection{Land Use Land Cover Classification and Accuracy Assessment}

The LULC of the study area for the years 2006 and 2017 and the LULC change are as in Table 2. Agriculture land, forest land and surface waterbodies decreased while built-up area and grassland increased during the study period. Built-up and grassland increased by $5.35 \%$ and $13.31 \%$ while agricultural land and forest land decreased by $13.22 \%$ and $5.41 \%$ respectively. Surface water bodies only increased by $0.03 \%$ despite the fact that there is an increase in utility dams in the Upper Chongwe River Catchment. Built-up land increased mostly along the Ngwerere River and mid-reach Chongwe River toward the lower Chongwe River. Further, the increase was mainly around the source of the Ngwerere River and the head waters of the Chalimbana River on the South of Lusaka City. Conversely, the lower part of the catchment, from Chongwe Rural to the confluence of the Chongwe and Zambezi Rivers, showed increase in bare land and a decrease in forest land. This could be attributed to increase in population forcing subsistence farmers to move from upstream where built-up land is on demand to downstream in the forest. This trend in land use land cover is attributed to an increase in demand for domestic, commercial and industrial land in the urban part of the catchment and extending steadily towards the rural part. More agricultural land is getting converted to urban built-up land while forest land is being cleared mainly for subsistence farming and charcoal burning [47] [48].

The above LULC results were adopted for further analysis based on the image classification accuracy assessment using the criteria shown in Table 3.

\subsection{Water Quality Analysis}

$\mathrm{pH}: \mathrm{pH}$ measurements taken on site ranged between 5.7 and 8.3 during the sampling period at all the sites. The values shown in the month of July on the upstream sites such as Ngwerere at the Weir and at Kalimba farm were as low as 5.7. These $\mathrm{pH}$ values were below the aquatic ecosystem limits according to guidelines prescribed in [36] [37]. The other sites were relatively within permissible limits for

Table 2. LULC distribution and change between 2006 and 2017 in the Chongwe River Catchment.

\begin{tabular}{ccccccc}
\hline \multirow{2}{*}{ LULC Class } & \multicolumn{2}{c}{2006} & \multicolumn{2}{c}{2017} & \multicolumn{2}{c}{ LULC Change } \\
\cline { 2 - 7 } & Area $\left(\mathrm{km}^{3}\right)$ & $\%$ & Area $\left(\mathrm{km}^{3}\right)$ & $\%$ & Area $\left(\mathrm{km}^{3}\right)$ & $\%$ \\
\hline Built-up area & 158.77 & 3.07 & 435.26 & 8.42 & 276.49 & 5.35 \\
Agriculture land & 972.41 & 18.81 & 289.28 & 5.60 & -683.13 & -13.22 \\
Forest land & 1347.29 & 26.07 & 1064.20 & 20.59 & -283.12 & -5.48 \\
Grass land & 2680.04 & 51.85 & 3368.16 & 65.16 & 688.12 & 13.31 \\
Water bodies & 10.17 & 0.20 & 11.78 & 0.23 & 1.61 & 0.03 \\
Total & 5168.68 & 100 & 5168.68 & 100 & & \\
\hline
\end{tabular}


Table 3. Image classification accuracy using producer's, user's, overall and Kappa coefficient.

\begin{tabular}{ccccccccc}
\hline \multirow{2}{*}{ LULC Class } & \multicolumn{2}{c}{$\begin{array}{c}\text { Producer's Accuracy } \\
\text { (\%) }\end{array}$} & \multicolumn{2}{c}{$\begin{array}{c}\text { User's Accuracy } \\
\text { (\%) }\end{array}$} & \multicolumn{2}{c}{$\begin{array}{c}\text { Overall } \\
\text { Accuracy (\%) }\end{array}$} & \multicolumn{2}{c}{$\begin{array}{c}\text { Kappa } \\
\text { Coefficient (\%) }\end{array}$} \\
\cline { 2 - 9 } & 2006 & 2017 & 2006 & 2017 & 2006 & 2017 & 2006 & 2017 \\
\hline Built-up area & 90.20 & 90.55 & 91.20 & 96.15 & & & & \\
Agriculture land & 88.90 & 90.25 & 82.05 & 80.45 & & & & \\
Forest land & 80.90 & 77.50 & 89.45 & 91.40 & 88.60 & 90.30 & 83.30 & 86.05 \\
Grassland & 80.50 & 86.25 & 86.00 & 81.70 & & & & \\
Waterbodies & 88.30 & 89.90 & 90.60 & 91.40 & & & & \\
\hline
\end{tabular}

drinking water according to [33] [34]. A pH between 7 and 8.5 is ideal for biological productivity.

Turbidity: Turbidity ranged from 2.6 - 13.5 NTU. The values of Site 2, 4 and 7 were above ZABS and WHO drinking water standards at $5 \mathrm{NTU}$. The rest of sites were within limits. The simple explanation of results shown at Site 2 and 4 is the contribution of effluent from Manchinchi Sewage Treatment plant and Kaunda Square Stabilization ponds respectively. The rest of the sites were within acceptable limits according to DWAF and ANZECC guidelines.

Conductivity and TDS: The values of onsite readings for EC and TDS ranged from 259.8 to 862.5 and 129.9 to 418.3 respectively, with maximum values measured at site 2, 3 and 4 . The results fell below the WHO and ZABS drinking water limits which are set 1500 and 1000 respectively. However, the maximum values at the sites 2, 3 and 4 reflect the pollution burden to aquatic systems exerted by partially treated sewage discharged into the Ngwerere River at those sites since site 2 and 3 are almost at the discharge points.

DO: The values of dissolved oxygen ranged from 4.8 to $7.8 \mathrm{mg} / \mathrm{l}$ with the lowest values read at site 1 and 2 . The WHO and ZABS maximum standard limit for $\mathrm{DO}$ is set at $5 \mathrm{mg} / \mathrm{L}$. Therefore, site 1 and 2 readings were below the acceptable limit. The low levels of DO shown mainly in the Ngwerere River are an indication of high level organic matter discharged into the river by the commercial facilities located close to Site 1 and the Sewage treatment plant near Site 2 and Site 3 [12] [49].

BOD and COD: BOD and COD were only conducted in July 2006 by WARMA and we used the same reading time to monitor these parameters in this study. Therefore, results shown analyzed here are not based on the given means and standard deviations by monthly readings for July 2006, 2017 and 2018. In results of July 2006, BOD and COD ranged from 3.6 to $7.3 \mathrm{mg} / \mathrm{L}$ and 5.3 to $11.5 \mathrm{mg} / \mathrm{L}$ respectively while during this study period, they ranged from 13 $17 \mathrm{mg} / \mathrm{L}$ and $24-30.4 \mathrm{mg} / \mathrm{L}$ in 2017/2018 readings respectively. The results for 2006 mostly did not meet the WHO and ZABS standard limits for drinking water but they were not far from the maximum limit. On the other hand, results for both parameters were all above drinking standards and aquatic ecosystem guidelines at all the sites. The extremely high BOD and COD concentrations obtained 
in the study showed an increase trend in the levels of organic compounds in the catchment surface water. The upstream Chongwe, sites 1, 2, 3 and 4 are being recharged with raw sewage while the mid-reach Chongwe is also being recharged with partially treated sewage by the rapidly developed new settlement on the head waters of the Chalimbana River, site 7 and 8. BOD and COD are typically used to indicate the degree of pollution in the river. Therefore, the results obtained gives an indication of the catchment surface water being polluted and apparently could be having a negative impact on the aquatic life.

Nitrates, Ammonia, Phosphates and Sulphates: The values of $\mathrm{NO}_{3}, \mathrm{NH}_{3}$ and $\mathrm{SO}_{4}^{2-}$ ranged from 0.7 to $27.5 \mathrm{mg} / \mathrm{L}, 0.3$ to $4.5 \mathrm{mg} / \mathrm{L}$ and 1.2 to $26.8 \mathrm{mg} / \mathrm{L}$ in July respectively. The phosphate results of 2006 and 2017/2018 during this study period ranged from 0.01 to $38 \mathrm{mg} / \mathrm{L}$ in February and from 0.01 to $4.86 \mathrm{mg} / \mathrm{L}$ in July. Nitrate and Ammonia were measured to assess the organic and inorganic nitrogen concentrations in the river. The results all fell within permissible limits of drinking water according to WHO and ZABS. However, an increase was observed during the month of February mainly at site 2, 3, 4, 8 and 9 compared to site 1 and 7. The observed increase could be attributed to increased concentration of organic and inorganic compounds discharged into the rivers by runoff during the rainy season. The sites affected are the most concentrated areas for agriculture activities in the catchment [24]. These findings are supported by other studies which have shown that nitrates, sulphates and phosphates are usually high in runoff around areas that are dominated by agricultural activities due to the application of the NPK fertilisers in the fields. Further, if these continue exceeding standard limits, cases of eutrophication would become prevalent.

Heavy metals $(\mathrm{Cd}, \mathrm{Cr}, \mathrm{Pb}, \mathrm{Fe})$ : The records of measurements conducted by WARMA provided more data on $\mathrm{K}^{+}, \mathrm{Na}^{+}$and $\mathrm{Fe}$ while $\mathrm{Cd}, \mathrm{Cr}$ and $\mathrm{Pb}$ did not have sufficient data. However, during this study, measurements were taken on the three parameters and results all showed $<0.001 \mathrm{mg} / \mathrm{L}$. The results of $\mathrm{K}^{+}, \mathrm{Na}^{+}$ and Fe analysis ranged from 3.4 to $45 \mathrm{mg} / \mathrm{L}, 1.8$ to $13.0 \mathrm{mg} / \mathrm{L}$ and 0.1 to $0.5 \mathrm{mg} / \mathrm{L}$ respectively. These results all fell within permissible limits for drinking water. This however, did not provide sufficient information to conclude heavy metal contamination is not present in the catchment. Perhaps, performing bottom sediments analysis for heavy metals would lead to a different inference.

Table 4 shows the descriptive statistics of the physicochemical parameters and heavy metals that were analyzed in this study. It can be seen from the Table that the parameters, especially the chemical ones, were generally below the minimum permissible limits.

\subsection{Trend Analysis of Water Quality}

The results of the Mann-Kendall trend test on water quality using available data in the WARMA database for July 2006 to July 2016 combined with this study's monitoring exercise for July 2017 and 2018 for the Chongwe River Catchment are given in Table 5. The tests were all done at the $\alpha$-value of 0.05 significant 
Table 4. Descriptive analysis of physicochemical parameters at different sampling sites

\begin{tabular}{cccccccccc}
\hline & S1 & S2 & S3 & S4 & S5 & S6 & S7 & S8 & S9 \\
\hline $\mathrm{pH}$ & $6.5 \pm 0.3$ & $6.7 \pm 0.2$ & $8 \pm 0.1$ & $6.6 \pm 0.5$ & $7.1 \pm 0.3$ & $7.4 \pm 0.2$ & $7.9 \pm 0.5$ & $8.3 \pm 0.1$ & $7.8 \pm 0.3$ \\
$\mathrm{EC}(\mu \mathrm{s} / \mathrm{cm})$ & $756 \pm 250.3$ & $837.5 \pm 334.5$ & $862.5 \pm 166.2$ & $259.8 \pm 235.1$ & $380 \pm 216.4$ & $558 \pm 205.1$ & $304 \pm 43.8$ & $438 \pm 89.1$ & $598 \pm 137.2$ \\
$\mathrm{Temp}\left({ }^{\circ} \mathrm{C}\right)$ & $23.4 \pm 1.3$ & $19.9 \pm 3.7$ & $20.8 \pm 3.8$ & $21.9 \pm 9.1$ & $19.4 \pm 6.6$ & $20.9 \pm 0.9$ & $20 \pm 4.7$ & $21.9 \pm 0.5$ & $18.4 \pm 4.6$ \\
$\mathrm{TDS}(\mathrm{mg} / \mathrm{L})$ & $379.5 \pm 123.7$ & $418.3 \pm 166.5$ & $465 \pm 35.4$ & $129.9 \pm 117.6$ & $189.3 \pm 107.1$ & $279.8 \pm 103.6$ & $151.8 \pm 21.6$ & $219 \pm 44.5$ & $298.3 \pm 67.5$ \\
$\mathrm{Turb}(\mathrm{NTU})$ & $2.6 \pm 3.7$ & $13.5 \pm 2.5$ & - & $10.2 \pm 0.1$ & - & - & - & - & $7.2 \pm 3.9$ \\
$\mathrm{Na}(\mathrm{mg} / \mathrm{L})$ & - & $32.9 \pm 14.5$ & $45.4 \pm 7.6$ & $27.1 \pm 11.5$ & $13.8 \pm 3.4$ & $24 \pm 9.9$ & $20.3 \pm 7.9$ & $13.5 \pm 5.4$ & $24.9 \pm 9.6$ \\
$\mathrm{~K}(\mathrm{mg} / \mathrm{L})$ & - & $11.6 \pm 3.9$ & $13 \pm 8.5$ & $3.2 \pm 3.8$ & $1.8 \pm 1.8$ & $6 \pm 2.9$ & $4.8 \pm 3.4$ & $3 \pm 2$ & $5.3 \pm 5.2$ \\
$\mathrm{Fe}(\mathrm{mg} / \mathrm{L})$ & - & $0.1 \pm 0.5$ & $0 \pm 0.1$ & $0.1 \pm 0$ & $0.3 \pm 0.4$ & - & - & - & $0.1 \pm 0.1$ \\
$\mathrm{DO}^{(\mathrm{mg} / \mathrm{L})}$ & $4.8 \pm 0.4$ & $4.1 \pm 0.6$ & $7.8 \pm 1.9$ & $6.6 \pm 0.3$ & $5.2 \pm 0.7$ & $5.2 \pm 0.4$ & $6.1 \pm 0.9$ & $6.3 \pm 0.4$ & $6.7 \pm 1.2$ \\
$\mathrm{NO}_{3}(\mathrm{mg} / \mathrm{L})$ & - & $6.85 \pm 2.62$ & - & $22.8 \pm 6.8$ & $27.5 \pm 12.4$ & $0.8 \pm 0.3$ & $0.8 \pm 0.3$ & $7.1 \pm 1.4$ & $0.7 \pm 0.4$ \\
$\mathrm{SO}_{4}^{2-}(\mathrm{mg} / \mathrm{L})$ & - & $26.8 \pm 0.3$ & $23.2 \pm 1.2$ & $20 \pm 7.9$ & $5.8 \pm 1.8$ & - & $14.2 \pm 4.6$ & $11.4 \pm 4.3$ & - \\
$\mathrm{NH}_{4}(\mathrm{mg} / \mathrm{L})$ & - & $4.5 \pm 0.47$ & - & $0.33 \pm 0.24$ & - & $0.53 \pm 0.12$ & - & $0.65 \pm 0.14$ & $0.79 \pm 0.014$ \\
\hline
\end{tabular}

Note: All for July 2006 to July 2018.

Table 5. Mann-Kendall's t test in the water quality of the Chongwe River Catchment.

\begin{tabular}{cccc}
\hline Parameter & Sen's Slope & p-value & Remarks \\
\hline $\mathrm{pH}$ & -0.011 & $<0.0001$ & There is significant trend \\
$\mathrm{EC}(\mathrm{mm} / \mathrm{cm})$ & 0.985 & 0.132 & There is no significant trend \\
Redox & 0.138 & 0.068 & There is no significant trend \\
Temp $\left({ }^{\circ} \mathrm{C}\right)$ & -0.019 & 0.232 & There is no significant trend \\
$\mathrm{DO}(\mathrm{mg} / \mathrm{l})$ & -0.013 & 0.027 & There is significant trend \\
$\mathrm{TDS}(\mathrm{mg} / \mathrm{l})$ & 0.763 & 0.039 & There is significant trend \\
\hline
\end{tabular}

level. The results showed a decreasing trend in $\mathrm{pH}$ and $\mathrm{DO}$ and an increasing trend in TDS over the catchment. The decreasing trend in $\mathrm{pH}$ and $\mathrm{DO}$ could be attributed to the increase in discharge of untreated sewage into the upper and middle parts of the catchment due to increase in built-up land. The untreated sewage are overflows from two of the three main sewage treatment plants located within this portion of the catchment [12] [49], which are operating beyond their design capacity. EC and Redox showed positive trend while temperature showed negative trend but this was not statistically significant.

\subsection{Hierarchical Cluster and Principal Component Analysis}

The results of the Hierarchical cluster analysis yielded two clusters as shown in Figure 3. As can be seen from the figure and based on the Euclidean distance, cluster 1 consisting of 6 Sites (S5, S4, S1, S8, S7, S6, and S9) was characterized by low Euclidean distance while Cluster 2 consisting of 2 Sites (S2 and S3) was characterized by a high Euclidean distance. 
Principal Component Analysis in Table 6 shows extraction of five factors. Factor 1 accounted for $33.37 \%$ of the total variance in the water quality parameters, with strong factor loadings of electrical conductivity, TDS, Sodium, Potassium and Chloride and moderate loading of $\mathrm{NO}_{3}$ and $\mathrm{SO}_{4}^{2-}$. The concentrations

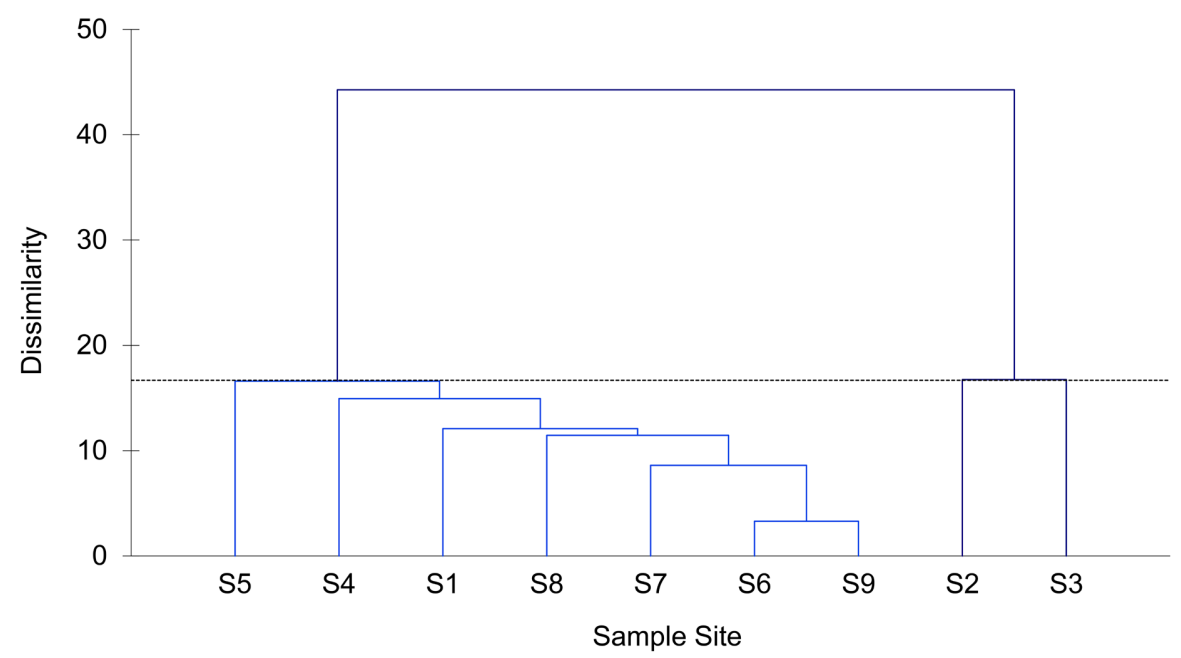

Figure 3. Dendrogram showing sampling site clusters along the Upper Chongwe River Catchment.

Table 6. Rotated Component Loading Matrix, Eigenvalues, Total Variance and Cumulative Variance.

\begin{tabular}{|c|c|c|c|c|c|}
\hline \multirow{2}{*}{ Variable } & \multicolumn{5}{|c|}{ Component } \\
\hline & 1 & 2 & 3 & 4 & 5 \\
\hline $\mathrm{EC} \mu \mathrm{s} / \mathrm{cm}$ & 0.918 & & & & \\
\hline TDS (mg/l) & 0.936 & & & & \\
\hline $\mathrm{Na}(\mathrm{mg} / \mathrm{l})$ & 0.889 & & & & \\
\hline $\mathrm{K}(\mathrm{mg} / \mathrm{l})$ & 0.978 & & & & \\
\hline $\mathrm{Cl}(\mathrm{mg} / \mathrm{l})$ & 0.814 & & & & \\
\hline $\mathrm{NO}_{3}$ & 0.636 & & & & \\
\hline $\mathrm{SO}_{4}^{2-}$ & 0.739 & & & & \\
\hline $\mathrm{NH}_{4}$ & & -0.674 & & & \\
\hline Turb NTU & & 0.642 & & & \\
\hline $\mathrm{Pb}(\mathrm{mg} / \mathrm{L})$ & & 0.862 & & & \\
\hline $\mathrm{Fe}(\mathrm{mg} / \mathrm{L})$ & & -0.713 & & & \\
\hline $\mathrm{pH}$ & & & 0.697 & & \\
\hline Temp $\left({ }^{\circ} \mathrm{C}\right)$ & & & & 0.711 & \\
\hline $\mathrm{DO}(\mathrm{mg} / \mathrm{L})$ & & & 0.602 & & 0.632 \\
\hline Eigenvalue & 5.980 & 3.471 & 2.010 & 1.604 & 1.360 \\
\hline Variability (\%) & 37.373 & 21.694 & 12.561 & 10.027 & 8.502 \\
\hline Cumulative (\%) & 37.373 & 59.067 & 71.628 & 81.655 & 90.157 \\
\hline
\end{tabular}


of these ions could be due to the presence of organic matter and organic acids which indicates the influence of anthropogenic activities and geological formations on water quality. The concentration of $\mathrm{NO}_{3}$ could be due to nitrification taking place in the rivers while the concentration of $\mathrm{SO}_{4}^{2-}$ could be due to fertilizer from runoff which indicates human influence especially agricultural activities. Factor 2 accounted for $21.69 \%$ of the total variance with strong factor loading of $\mathrm{Pb}$ and moderate factor loadings of $\mathrm{NH}_{4}$, Turbidity, and Fe. This could be attributed to the sediment runoff from loose soils on agricultural lands into the rivers. Factor 3 accounted for $12.56 \%$ of the total variance in the water quality parameters and revealed moderate factor loadings of $\mathrm{pH}$ and $\mathrm{DO}$ indicating that despite domestic waste being discharged into the river, there is oxygen availability and sufficient $\mathrm{pH}$ levels to support aquatic life. Factor 4 accounted for $10.02 \%$ of the total variance with a moderate loading of temperature indicating the effects of shading of riparian forest which influences water temperature and aquatic productivity. Factor 5 accounted for $8.50 \%$ of the total variance with moderate loading of DO from domestic waste discharge. Similar findings were reported by Ayeni and Soneyanu [50] that land uses such as domestic and agricultural activities strongly influence the variation of the quality of surface water.

The variables from component loadings shown in Table 6 where then grouped according to their designated components and classified their factor loading as shown in Table 7. The factor loadings were classified "Strong", "Moderate" and "Weak" corresponding to absolute loading values of $>0.75,0.75-0.50$ and $0.50-$ 0.30 , respectively [29].

\subsection{Weighted Arithmetic Water Quality Index}

Table 8 shows the water quality index calculated and ranking of water quality at the 9 sites for July 2006 and July 2017. The results of water quality index calculations on all 9 sites showed generally that there has been a deterioration of the quality of water in the Upper Chongwe River Catchment between 2006 and 2017. This was observed when WQI results of 2006 could be ranked into good, poor, very bad and unsuitable for drinking while the results for the same sites in 2017 all came out unsuitable for drinking. The results showed that in 2006, the WQI ranged from 45.03 (Good) to 110.40 (unsuitable for drinking). In 2017, the

Table 7. Factor loading classification of variables into strong, moderate or weak.

\begin{tabular}{|c|c|c|c|}
\hline \multirow{2}{*}{ Component } & \multicolumn{3}{|c|}{ Variables } \\
\hline & Strong $(>0.75)$ & Moderate $(0.75-0.50)$ & Weak $(0.50-0.30)$ \\
\hline 1 & $\mathrm{EC}, \mathrm{TDS}, \mathrm{Na}^{+}, \mathrm{K}^{+}, \mathrm{Cl}^{-}, \mathrm{NO}_{3}$, & $\mathrm{SO}_{4}^{2-}$ & \\
\hline 2 & $\mathrm{~Pb}(\mathrm{mg} / \mathrm{L})$ & $\mathrm{NH}_{4}$, Turb (NTU), Fe (mg/L) & \\
\hline 3 & & $\mathrm{pH}, \mathrm{DO}(\mathrm{mg} / \mathrm{L})$ & \\
\hline 4 & & Temp $\left({ }^{\circ} \mathrm{C}\right)$ & \\
\hline 5 & & $\mathrm{DO}(\mathrm{mg} / \mathrm{L})$ & \\
\hline
\end{tabular}


Table 8. WQI and ranking of water quality in Upper Chongwe River Catchment for 07/2006 and 07/2017.

\begin{tabular}{|c|c|c|c|c|c|c|}
\hline \multirow{2}{*}{$\begin{array}{c}\text { Sample Site } \\
\text { ID }\end{array}$} & \multicolumn{3}{|c|}{ July 2006} & \multicolumn{3}{|c|}{ July 2017} \\
\hline & $\mathrm{W}_{\mathrm{i}} \mathrm{Q}_{\mathrm{i}}$ & WQI & Classification (QI) & $\mathrm{W}_{\mathrm{i}} \mathrm{Q}_{\mathrm{i}}$ & WQI & Classification (QI) \\
\hline S1 & - & - & - & 198.92 & 170.1 & Unsuitable for drinking \\
\hline $\mathrm{S} 2$ & 105.58 & 90.26 & Very bad & 267.13 & 228.38 & Unsuitable for drinking \\
\hline S3 & 114.51 & 97.89 & Very bad & 503.44 & 430.4 & Unsuitable for drinking \\
\hline S4 & 129.10 & 110.40 & Unsuitable for drinking & 237.17 & 202.8 & Unsuitable for drinking \\
\hline S5 & - & - & - & 388.12 & 331.8 & Unsuitable for drinking \\
\hline S6 & 52.68 & 45.03 & Good & 296.88 & 253.1 & Unsuitable for drinking \\
\hline S7 & 62.86 & 53.74 & Poor & 284.68 & 243.4 & Unsuitable for drinking \\
\hline S8 & 60.10 & 51.38 & Poor & 352.21 & 301.1 & Unsuitable for drinking \\
\hline S9 & 83.085 & 71.03 & Poor & 405.78 & 346.9 & Unsuitable for drinking \\
\hline
\end{tabular}

Note: $\mathrm{W}_{\mathrm{i}} \mathrm{Q}_{\mathrm{i}}$ is the Sub-index-SI, WQI is the water quality index and QI is the quality index ranking criteria.

WQI ranged from 170.10 to 430.40 (unsuitable for drinking) indicating a clear deterioration of surface water quality in the whole upper catchment.

The WQI results showed that water in the Ngwerere was unsuitable for drinking in 2006 as well as 2017. The steady degrading trend in water quality of the Ngwerere River due to pollution in catchment has been noted and attributed to increased levels of anthropogenic domestic and agricultural activities along its banks [49]. According to Hahne, Shamboko-Mbale, and Bäumle [12] large volumes of untreated sewage are discharged into the Ngwerere River and an uncontrolled use of agrochemicals and discharge of industrial waste into the upstream areas of the Chongwe River. Furthermore, the Ngwerere Stream, which is a significant source of water for the Lusaka Water Supply and Sanitation Company treatment plant at Chongwe Dam, receives highly polluted discharges from overburdened wastewater treatment works in Lusaka City.

The Kanakantapa makes up the middle part of the catchment. During the ground truthing exercise, it was noted to be more of rural settlements than urban and was predominantly occupied by subsistence farmers. This could be the reason why WQI results for 2006 showed "good" water quality in Kanakantapa River. However, the LULC classification results for 2006 and 2017 showed significant increase in built-up and agricultural land around the Kanakantapa River. This partly explains why in 2017, the WQI results showed that water was unsuitable for drinking. Another, reason could that the Chongwe River Catchment had not been receiving good number of rains between 2012 and 2015 to support dilution of heavy organic matter being discharged upstream as water flows downstream. The other mid-reach of the catchment is Site (7) which is a crucial monitoring point for the impact of upstream physic-chemical activities. The 2006 WQI results for this site further showed that water in the mid-reach Chongwe River was good to poor. However, 2017 WQI results indicate that water quality has degraded to being unsuitable for drinking. 
Site 8 and 9 (long Chalimabana River) makes up the lower part of the catchment. The 2006-2017 LULC classification results showed increase in built-up land area in the head waters of the Chalimbana River. The change was also reflected by the change in WQI results from poor to unsuitable for drinking between 2006 and 2017. The degradation of water quality is increase by anthropogenic domestic, commercial and agricultural activities in the head water of the Chalimabana River. This could be explained by the upstream-downstream usage conflicts among farms [50] [51].

The Chongwe River Catchment has undergone significant parallel change of LULC and water quality (Figure 4). The increase in built-up area shown in the upper part of the catchment could have had an impact on water quality whereby WQI results of the Ngwerere which was 100 in 2006 degraded to above 100 in 2017 rendering the water unsuitable for drinking. Further, these results showed that Ngwerere River has been the most impact by LULC with Site 1, 2, 3 and 4 having WQI ranging between 90 - 110 in 2006 and 170 - 430.4 in 2017. A physical check of the effluent from the Kaunda Stabilisation Ponds went through Meanwood Kwamwena Valley was discharged as raw sewer and ended up in Ngwerere stream. These results indicate that water quality in the upper catchment has been change from very bad to unsuitable for drinking. The mid-reach Chongwe which was once in the range of 45 - 55 in 2006 showed extreme change in 2017, ranging between 243 - 33. The lower Chongwe also ranged in the extreme values of 301 - 346 in 2017 from the range of 51 - 71 in 2006. These changes in the lower Chongwe could be attributed to increased growth of built-up land and agricultural activities on the head waters of the Chalimabana River.

\subsection{Relationship between LULC and Water Quality}

The relationship between land-use and water quality is presented in Table 9, using the Pearson correlation. The results reveal that built-up/bare lands exhibited a significant positive correlation with EC $\left(R^{2}=0.61, \mathrm{p} \leq 0.05\right)$, turbidity $\left(R^{2}\right.$ $=0.69, \mathrm{p} \leq 0.05)$, TDS $\left(R^{2}=0.61, \mathrm{p} \leq 0.05\right), \mathrm{Cl}\left(R^{2}=0.62, \mathrm{p} \leq 0.05\right)$ and a significant negative correlation with $\mathrm{NH}_{4}\left(R^{2}=-0.729, \mathrm{p} \leq 0.05\right)$. Agriculture exhibited a significant positive correlation with turbidity $\left(R^{2}=0.71, \mathrm{p} \leq 0.01\right)$ and $\mathrm{Fe}$ $\left(R^{2}=0.75, \mathrm{p} \leq 0.01\right.$. Forest cover correlated negatively with most of the water quality parameters apart from $\mathrm{Fe}, \mathrm{DO}, \mathrm{NO}_{3}$. However this correlation was not statistically significant. Grassland had a significant negative correlation with temperature $\left(R^{2}=-0.68, \mathrm{p} \leq 0.05\right)$.

Findings from a number of studies have established trends of the impact of urban, agricultural and forest land use on water quality [52] [53] [54] [55]. For example, Yadav et al. [55] revealed a positive correlation of total phosphorus (TP) with urban land use and attributed it to point sources such as treatment plants, domestic sewers, wastewater treatment plants and industries. In this study, built-up and agricultural land appeared to be the most important predictors of water quality variability. The positive correlation between built-up/bare 


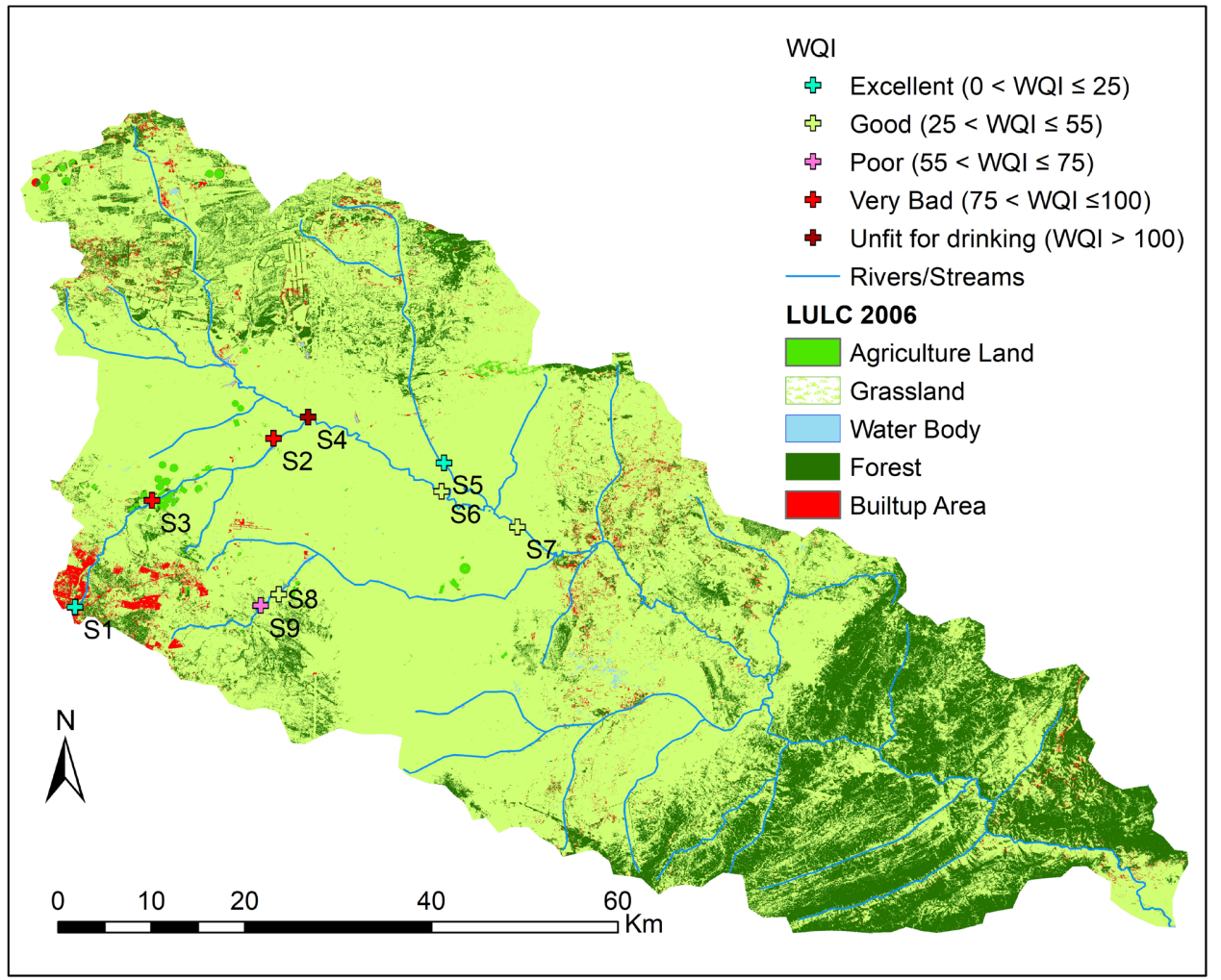

(a)

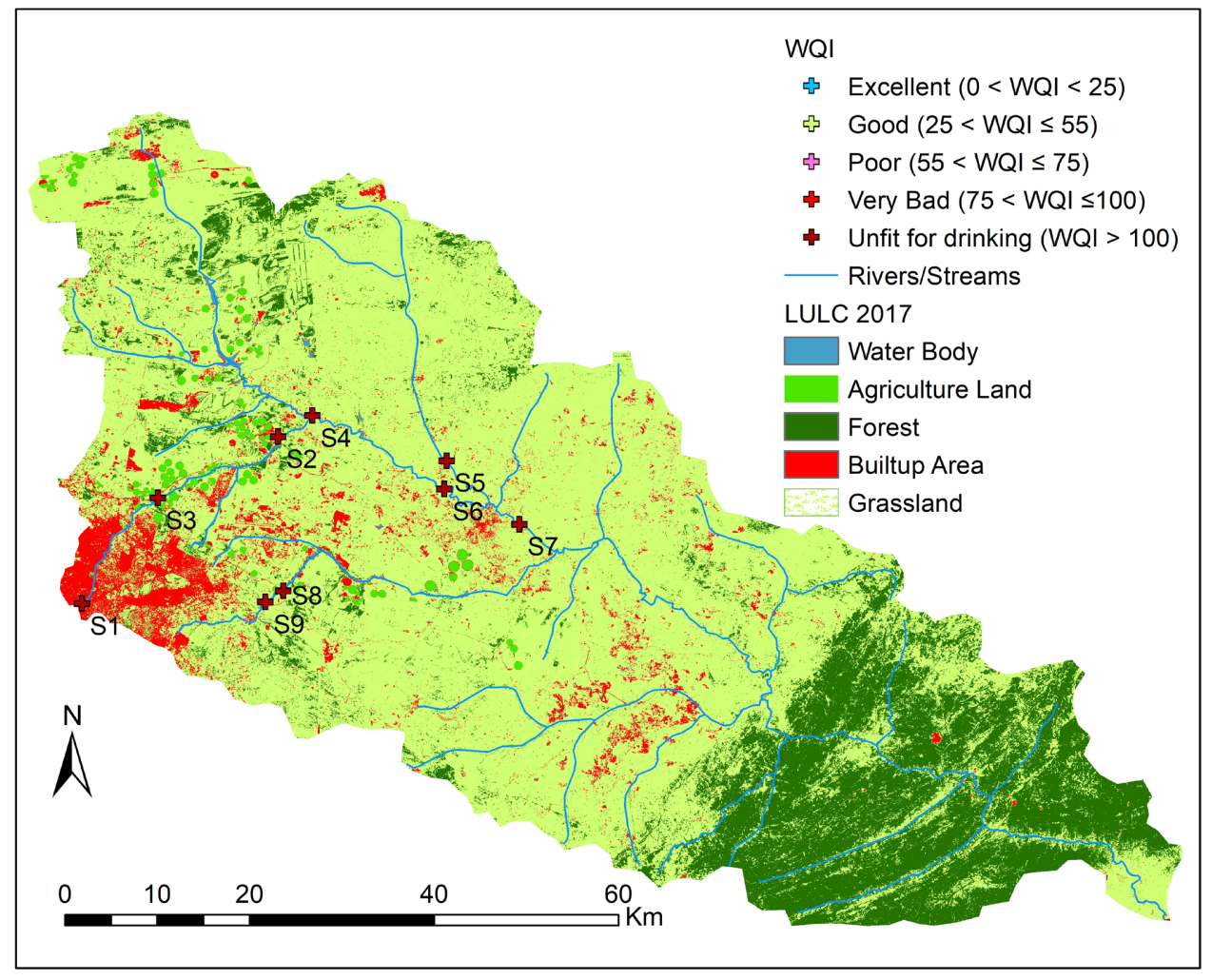

(b)

Figure 4. Land use land cover and surface water quality of the Chongwe River Catchment in (a) 2006 and (b) 2017. 
Table 9. Pearson correlation between land-use types and water quality parameters in Upper Chongwe River Catchment.

\begin{tabular}{ccccc}
\hline Parameter & Forest & Grassland & Agriculture & Built-up \\
\hline $\mathrm{pH}$ & -0.39 & -0.36 & -0.06 & 0.11 \\
$\mathrm{EC}$ & -0.21 & -0.57 & 0.47 & 0.61 \\
$\mathrm{Temp}$ & -0.54 & -0.68 & 0.21 & 0.52 \\
$\mathrm{TDS}$ & -0.21 & -0.57 & 0.47 & 0.61 \\
$\mathrm{Turb}$ & -0.27 & -0.54 & 0.71 & 0.69 \\
$\mathrm{Na}^{+}$ & -0.18 & -0.57 & 0.37 & 0.55 \\
$\mathrm{Cl}^{-}$ & -0.29 & -0.52 & 0.36 & 0.62 \\
$\mathrm{Fe}$ & 0.01 & -0.29 & 0.75 & 0.42 \\
$\mathrm{DO}^{-}$ & 0.14 & -0.10 & -0.30 & -0.39 \\
$\mathrm{NO}_{3}$ & 0.14 & -0.14 & -0.02 & 0.09 \\
$\mathrm{NH}_{4}$ & -0.143 & & -0.179 & -0.929 \\
\hline
\end{tabular}

land and TDS, conductivity, $\mathrm{Cl}$, and turbidity are most likely to be ascribed to sediment runoff from construction sites, weathering of rocks and erosion from bare areas [56]. Road salts can be a great contributor to chlorides in receiving waters [57]. The positive correlation between agricultural lands and turbidity and $\mathrm{Fe}$ could likely be attributed to the sediment runoff from loose soils on agricultural lands into the river [55]. Forest and grassland depicted negative correlation with water quality parameters. This indicates that as forest land increases, degraded water quality decreases and vice versa. As observed by Sliva \& Williams [52], vegetation can improve water quality deterioration by absorbing nutrients and blocking sediment runoff. Tu [15] revealed similar results, indicating forest and grasslands as indicators for good water quality.

\section{Conclusions and Recommendations}

\subsection{Conclusion}

The aim of this study was to analyse and understand the response of surface water quality to LULC change in the rapidly urbanizing Chongwe River Catchment, in Zambia. Clearly, there has been a dramatic change in the land use land cover between 2006 and 2017. There is a notable change in Built-up land and Grassland showing an increase whereas Agricultural land and Forest land have decreased during the reference period. Surface water quality in the catchment has degraded between 2006 and 2017. Surface water quality depends on both natural and anthropological factors. In this study, four land use types of built-up, agriculture, forest and grassland showed significant correlation with water quality parameters. Among them, built-up and agricultural land had significant negative effects on water quality while forest and vegetation were the opposite. This was due to the increase in the impervious surface of the settlement land, high-intensity of human activities, discharge of untreated sewage rich in organic content and 
the spatial distribution of built-up land in the catchment. Non-point source pollution caused by agriculture is another an important factor of water pollution. The findings and methods used in this study could be useful to identify the sources of pollution and improve water management and land use planning within the catchment.

\subsection{Recommendations}

From the conclusions drawn, the following measures are recommended:

- Buffering of the riparian zone should be implemented through Water User Association groups around the catchment.

- Vegetation is very important for water conservation and regulation of water quality. The protection and management of vegetation and forest should be emphasized. At the same time, the conversion and development of bare soil into agricultural land and settlement land is also an important reason for the deterioration of water quality. Relevant departments and staff should pay attention to this issue.

- Extending the enforcement of the Water Resources Management Act to monitoring and mitigation of surface water as its neglect has even more disastrous effects on the catchment considering its population growth rate against water demand among users for domestic, industrial and agricultural purposes.

- Investment in an integrated water quality management system which encompasses physical, chemical and biological indicators of water quality and prioritizes monitoring and mitigation according to the land use land cover distribution in the catchment, equipped with an up to date geospatial, physic-chemical and biological database.

- Establish an integrated sewer waste treatment within the catchment where the sludge could be scoped and properly managed while the effluent be properly monitored using real time monitoring at the point of discharge.

\section{Acknowledgements}

The authors' wish to acknowledge the Zambia Water Resources Management Agency for giving access to the monthly water quality database.

\section{Conflicts of Interest}

The authors declare no conflicts of interest regarding the publication of this paper.

\section{References}

[1] Reed, P.M., et al. (2006) Bridging River Basin Scales and Processes to Assess Human-Climate Impacts and the Terrestrial Hydrologic System. Water Resources Research, 42, W07418. https://doi.org/10.1029/2005WR004153

[2] Ayivor, J.S. and Gordon, C. (2012) Impact of Land Use on River Systems in Ghana. West African Journal of Applied Ecology, 20, 83-95. 
[3] Tong, S.T. and Chen, W. (2002) Modeling the Relationship between Land Use and Surface Water Quality. Journal of Environmental Management, 66, 377-393. https://doi.org/10.1006/jema.2002.0593

[4] Ahearn, D.S., Sheibley, R.W., Dahlgren, R.A., Anderson, M., Johnson, J. and Tate, K.W. (2005) Land Use and Land Cover Influence on Water Quality in the Last Free-Flowing River Draining the Western Sierra Nevada, California. Journal of Hydrology, 313, 234-247. https://doi.org/10.1016/j.jhydrol.2005.02.038

[5] Forney, W., Richards, L., Adams, K.D., Minor, T.B., Rowe, T.G., Smith, J.L. and Raumann, C.G. (2001) Land Use Change and Effects on Water Quality and Ecosystem Health in the Lake Tahoe Basin, Nevada and California. US Geological Survey Open-File Report, 01-418. https://doi.org/10.3133/ofr01418

[6] Hua, A.K. (2017) Land Use Land Cover Changes in Detection of Water Quality: A Study Based on Remote Sensing and Multivariate Statistics. Journal of Environmental and Public Health, 2017, Article ID: 7515130.

https://doi.org/10.1155/2017/7515130

[7] Huang, J., Zhan, J., Yan, H., Wu, F. and Deng, X. (2013) Evaluation of the Impacts of Land Use on Water Quality: A Case Study in the Chaohu Lake Basin. The Scientific World Journal, 2013, Article ID: 329187. https://doi.org/10.1155/2013/329187

[8] Central Statistical Office (2011) Zambia 2010 Census of Population and Housing-Preliminary Report. Lusaka, 66 p.

[9] Bäumle, R., Nick, A., Shamboko-Mbale, B., Siwale, C. and Kang'omba, S. (2012) Groundwater Resources of the Mwembeshi and Chongwe Catchments Including the Lusaka Region-A Brief Description of Physiography, Geology, Climate, Hydrology and the Groundwater Systems of the Area. Brochure Prepared by Department of Water Affairs (DWA), Zambia \& Federal Institute for Geosciences and Natural Resources (BGR), Lusaka, 65 p.

[10] Mucheleng'anga, G., Turton, A., Mbawo, E., Ng’oma, M., Mukubesa, L. and Musonda, W. (2002) Water Demand Management, Natural Resource Reconstruction and Social Adaptive Capacity: A Case Study from Chongwe-Chalimbana Area of Zambia, Water Research Commission (WRC). The Biennial Conference of the Water Institute of Southern Africa (WISA), Durban, 19-23 May 2002.

[11] Kang'omba, S. and Bäumle, R. (2013) Development of a Groundwater Information \& Management Program for the Lusaka Groundwater Systems-Key Recommendations and Findings. Final Report Prepared by Department of Water Affairs (DWA), Zambia \& Federal Institute for Geosciences and Natural Resources (BGR), Lusaka, $77 \mathrm{p}$.

[12] Hahne, K., Shamboko-Mbale, B. and Bäumle, R. (2011) Land Use Map of Lusaka and Surroundings, Scale 1:200,000. Map Prepared by Department of Water Affairs (DWA), Zambia \& Federal Institute for Geosciences and Natural Resources (BGR), Lusaka.

[13] Li, S., Gu, S., Liu, W., Han, H. and Zhang, Q. (2008) Water Quality in Relation to Land Use and Land Cover in the Upper Han River Basin, China. Catena, 75, 216-222. https://doi.org/10.1016/j.catena.2008.06.005

[14] Chen, D., Elhadji, A., Xu, H., Xu, X. and Qiao, Z. (2020) A Study on the Relationship between Land Use Change and Water Quality of the Mitidja Watershed in Algeria Based on GIS and RS. Sustainability, 12, 3510. https://doi.org/10.3390/su12093510

[15] Tu, J. (2011) Spatially Varying Relationships between Land Use and Water Quality across an Urbanization Gradient Explored by Geographically Weighted Regression. 
Applied Geography, 31, 376-392. https://doi.org/10.1016/j.apgeog.2010.08.001

[16] Tran, C.P., Bode, R.W., Smith, A.J. and Kleppel, G.S. (2010) Landuse Proximity as a Basis for Assessing Stream Water Quality in New York State (USA). Ecological Indicators, 10, 727-733. https://doi.org/10.1016/j.ecolind.2009.12.002

[17] Shi, P., Zhang, Y., Li, Z.B., Li, P. and Xu, G.C. (2017) Influence of Land Use and Land Cover Patterns on Seasonal Water Quality at Multi-Spatial Scales. Catena, 151, 182-190. https://doi.org/10.1016/j.catena.2016.12.017

[18] Ding, J., Jiang, Y., Liu, Q., Hou, Z., Liao, J., Fu, L. and Peng, Q. (2016) Influences of the Land Use Pattern on Water Quality in Low-Order Streams of the Dongjiang River Basin, China: A Multi-Scale Analysis. Science of the Total Environment, 551-552, 205-216. https://doi.org/10.1016/j.scitotenv.2016.01.162

[19] Zhang, J., Li, S., Dong, R., Jiang, C. and Ni, M. (2019) Influences of Land Use Metrics at Multi-Spatial Scales on Seasonal Water Quality: A Case Study of River Systems in the Three Gorges Reservoir Area, China. Journal of Cleaner Production, 206, 76-85. https://doi.org/10.1016/j.jclepro.2018.09.179

[20] (2001) British Geological Survey, Groundwater Quality: Zambia.

[21] Nick, A. (2015) The Chongwe Catchment: A Hydrological, Hydrogeological and Hydrochemical Characterization for the Establishment of a Catchment Management Plan. Technical Report No. 2, Ministry of Energy and Water Development, Lusaka.

[22] Tena, M.T., Mwaanga, P. and Nguvulu, A. (2019) Impact of Land Use/Land Cover Change on Hydrological Components in Chongwe River Catchment. Sustainability, 11, 6415. https://doi.org/10.3390/su11226415

[23] Garrard, P. (1968) The Geology of the Chainama Hills Area. Ministry of Lands and Mines, Geological Survey Report No. 24, Government Printer, Lusaka.

[24] Millennium Challenge Corporation (MCC) (2011) Water Supply Investment Master Plan. Lusaka.

[25] Siwale, C. and Bäumle, R. (2012) Hydrological/Hydrogeological Year Book of the Mwembeshi and Chongwe Sub-Catchments, 2009/10 and 2010/11. Ministry of Mines, Energy and Water Development, Department of Water Affairs, Lusaka, 65 p.

[26] YEC Yachiyo Engineering Co. Ltd. (1995) The Study on the National Water Resources Master Plan in the Republic of Zambia. Japan International Cooperation Agency and Republic of Zambia, Ministry of Energy and Water Development, Final Report, Supporting Volume 1, Lusaka.

[27] Liu, C.W., Lin, K.H. and Kuo, Y.M. (2003) Application of Factor Analysis in the Assessment of Groundwater Quality in a Blackfoot Disease Area in Taiwan. Science of the Total Environment, 313, 77-89. https://doi.org/10.1016/S0048-9697(02)00683-6

[28] Lambin, E.F. (2001) The Causes of Land-Use and Land Cover Change: Moving Beyond the Myths. Global Environmental Change, 11, 261-269. https://doi.org/10.1016/S0959-3780(01)00007-3

[29] Jensen, P.S. (2006) Inhibition of Motor Responses in Siblings Concordant and Discordant for Attention Deficit Hyperactivity Disorder. Yearbook of Psychiatry and Applied Mental Health, 2006, 29. https://doi.org/10.1016/S0084-3970(08)70031-8

[30] Environmental Protection Agency (EPA) (2001) Parameters of Water Quality: Interpretation and Standard. Johnson Castle Co., Wexford.

[31] World Health Organization (WHO) (2011) Guidelines for Drinking Water Quality. Fourth Edition, World Health Organization, Geneva. 
[32] (2010) Zambian Standard (ZS), First Revision. Drinking Water Quality-Specification. Zambia Bureau of Standards, Lusaka.

[33] APHA (American Public Health Association) (2001) Standard Methods for the Examination of Water and Wastewater. 20th Edition, APHA, Washington DC.

[34] Gautam, S.P., Reeta, K., Suniti, P., Basu, D.D. and Kamyotra, J.S. (2005) Guide Manual: Water and Waste Water Analysis. Central Pollution Control Board, Ministry of Environment and Forests, Government of India.

[35] Zambia Environmental Management Agency (ZEMA) (2013) Limits for Effluent and Waste Water. Regulatory 7 (2). Statutory Instruments, Third Schedule.

[36] Australian Guidelines for Water Quality Monitoring and Reporting/Australian and New Zealand Environment and Conservation Council, Agriculture and Resource Management Council of Australia and New Zealand. National Water Quality Management Strategy, No .7.

[37] Zeleňáková, M., Vido, J., Portela, M.M., Purcz, P., Blištán, P., Hlavatá, H. and Hluštík, P. (2017) Precipitation Trends over Slovakia in the Period 1981-2013. Water, 9, 922. https://doi.org/10.3390/w9120922

[38] Antonopoulos, V., Papamichail, D. and Mitsiou, K. (2001) Statistical and Trend Analysis of Water Quality and Quantity Data for the Strymon River in Greece. $\mathrm{Hy}$ drology and Earth System Sciences, 5, 679-691.

https://doi.org/10.5194/hess-5-679-2001

[39] Pohlert, T. (2018) Non-Parametric Trend Tests and Change-Point Detection. https://cran.r-project.org/web/packages/trend/vignettes/trend.pdf

[40] Ayeni, A.O., Kapangaziwiri, E., Soneye, A.S.O. and Engelbrecht, F.A. (2015) Assessing the Impact of Global Changes on the Surface Water Resources of Southwestern Nigeria. Hydrological Sciences Journal, 60, 1956-1971.

[41] Ayeni, A.O. and Soneyen, A.S.O. (2015) Interpretation of Surface Water Quality Using Principal Components Analysis and Cluster Analysis. Journal of Geography and Regional Planning, 6, 132-141. https://doi.org/10.5897/JGRP12.087

[42] Avvannavar, S.M. and Shrihari, S. (2008) Evaluation of Water Quality Index for Drinking Purposes for River Nethravathi, Mangalore, South India. Environmental Monitoring and Assessment, 143, 279-290. https://doi.org/10.1007/s10661-007-9977-7

[43] Akoteyon, I.S., Omotayo, A.O., Soladoye, O. and Olaoye, H.O. (2011) Determination of Water Quality Index and Suitability of Urban River for Municipal Water Supply in Lagos, Nigeria. European Journal of Scientific Research, 54, 263-271.

[44] Boah, D.K., Twum, S.T. and Pelig-Ba, K.B. (2015) Mathematical Computation of Water Quality Index of Vea Dam in Upper East Region of Ghana. Environmental Sciences, 3, 11-16. https://doi.org/10.12988/es.2015.4116

[45] Atulegwu, P.U. and Njoku, J.D. (2004) The Impact of Biocides on the Water Quality. International Research Journal of Engineering Science, Technology and Innovation, 1, 47-52.

[46] Chidumayo, E.N. (2001) Climate and Phenology of Savanna Vegetation in Southern Africa. Journal of Vegetation Science, 12, 347-354. https://doi.org/10.2307/3236848

[47] Hahne, K. and Shamboko-Mbale, B. (2010) Karstification, Tectonics and Land Use in the Lusaka Region. Report No. 3, Department of Water Affairs (DWA), Zambia and Federal Institute for Geosciences and Natural Resources (BGR), Lusaka, 76 p.

[48] Wamukwamba, C.K. and Share, W. (2001) Sewage Waste Management in the City of Lusaka. Loughborough University. Conference Contribution. 
https://hdl.handle.net/2134/28945

[49] Government of the Republic of Zambia (2014) Chongwe District Development Coordinating Committee. Annual Report.

[50] Kabika, J., Nyambe, A.I., Nkhuwa, W. and Chimambo (2007) Water Resource Conflict in Chalimbana River Catchment-A Case Study. Dept. of Civil Engineering, School of Engineering, University of Zambia, Lusaka.

[51] Food and Agriculture Organization of the United Nations (2011) The State of the World's Land and Water Resources for Food and Agriculture (SOLAW)-Managing Systems at Risk. Earthscan, London.

[52] Sliva, L. and Williams, D.D. (2001) Buffer Zone versus Whole Catchment Approaches to Studying Land Use Impact on River Water Quality. Water Research, 35, 3462-3472. https://doi.org/10.1016/S0043-1354(01)00062-8

[53] Ou, Y., Wang, X., Wang, L. and Rousseau, A.N. (2016) Landscape Influences on Water Quality in Riparian Buffer Zone of Drinking Water Source Area, Northern China. Environmental Earth Sciences, 75, 114.

https://doi.org/10.1007/s12665-015-4884-7

[54] Gu, Q., Hu, H., Ma, L., Sheng, L., Yang, S., Zhang, X., Zhang, M., Zheng, K. and Chen, L. (2019) Characterizing the Spatial Variations of the Relationship between Land Use and Surface Water Quality Using Self-Organizing Map Approach. Ecological Indicators, 102, 633-643. https://doi.org/10.1016/j.ecolind.2019.03.017

[55] Yadav, S., Babel, M.S., Shrestha, S. and Deb, P. (2019) Land Use Impact on the Water Quality of Large Tropical River: Mun River Basin, Thailand. Environmental Monitoring and Assessment, 191, 614. https://doi.org/10.1007/s10661-019-7779-3

[56] Kusimi, J.M. (2009) Analysis of Sedimentation Rates in the Densu River Channel: The Result of Erosion and Anthropogenic Activities in the Densu Basin. West African Journal of Applied Ecology, 14, 44703. https://doi.org/10.1007/s10661-019-7779-3

[57] Granato, G.E., DeSimone, L.A., Barbaro, J.R. and Jeznach, L.C. (2015) Methods for Evaluating Potential Sources of Chloride in Surface Waters and Groundwaters of the Conterminous United States. Open File Report 2015-1080. US Geological Survey, Reston. https://doi.org/10.3133/ofr20151080 